\title{
CONCENTRATIONS OF BROMINATED FLAME RETARDANTS IN PLASTICS OF ELECTRICAL AND ELECTRONIC EQUIPMENT, VEHICLES, CONSTRUCTION, TEXTILES AND NON-FOOD PACKAGING: A REVIEW OF OCCURRENCE AND MANAGEMENT
}

\section{Pierre Hennebert *}

INERIS - RISK/COSM, ARDEVIE La Villa Av Louis Philibert BP 33, Aix-en-Provence Cedex 4 13545, France

Article Info:
Received:
19 December 2019
Revised:
11 February 2020
Accepted:
26 March 2020
Available online:
25 July 2020
Keywords:
PBDE
DecaBDE
HBCDD
TBBPA
Sorting

\section{INTRODUCTION}

The EU is developing a strategy on plastics in a circular economy (EC 2017). Some plastic flows have a low rate of recycling and reuse of plastics due to, among other reasons, quality issues (presence of additives or mixing of different types of polymers). On the other hand, scientific progress in knowledge of substances results in the restriction or banning of elements or substances in products, and restricted management options when these substances are present in waste. This happens frequently as a legacy of previous practices. Research is active in this field. Human biomonitoring of global populations has identified an exposure to a range of plastic additives, detectable in some cases in most people (Galloway et al. 2019). A database of chemicals associated with (food) plastic packaging found 906 chemicals identified as likely, 3377 chemicals as possibly associated; the 148 most hazardous of them being classified in the CLP the United Nations' Globally Harmonized System (GHS). Some are classified as persistent, bioaccumulative and toxic (PBT) or very persistent and very bi- oaccumulative (vPvB), and endocrine disrupting chemicals (EDC) (Groh et al. 2019). A general overview of the plastic waste management options and the additives presents in plastics can be found in Hahladakis et al. (2018). The conclusion is that recycled plastics must be sorted in order to avoid the spreading of some unwanted additives in the new products.

The use of plastics in Europe is divided as follows: $39.7 \%$ for packaging (food- and non-food-), $19.8 \%$ for building and construction, $16.7 \%$ for medical equipment, plastic furniture and furniture equipment, technical parts used for mechanical engineering or machine-building, $10.1 \%$ for automotive, $6.2 \%$ for electrical and electronic equipment, $4.1 \%$ for household, leisure and sport, the rest being used in agriculture (3.4\%) (PlasticsEurope 2018). For instance, hard plastics and foams now account for about $150 \mathrm{~kg}$ in modern cars, $16 \%$ of which could be brominated (this study). They are protected against fire with, among others, brominated flame retardants (BFR), some of them being now classified as hazardous or persistent organic pollut- 
ants (POP). An important review on POP substances including BFRs in plastics is (EC 2011).

The compilation of PBDE production data prepared for the POPs Reviewing Committee of the Stockholm Convention estimated the total production of all PBDE from 1970 to 2005 as between 1.3 million and 1.5 million tons (UNEP 2017a). DecaBDE production is estimated at between 1.1 and 1.25 million tons. The three largest producers are Israel Chemical Limited - Industrial Products (ICL), Albemarle Corporation and Chemtura - Great lakes Solutions. They offer products or additives for construction (particularly insulation foam of polystyrene and polyurethane), electrical and electronic equipment (EEE), transport, electrical wires, coal flue gas cleaning, agriculture and oil refining, among others (Albemarle 2018, Chemtura 2018, ICL 2012). A huge variety of BFR is produced. ICL has a specific product guide "Fire protection for automotive and transportation". The BFR are used in different polymers in the $1-15 \%$ range (Arias 2011, Alaee et al. 2003).

To assess the concentration of POP substances in the end-of-life plastics, published or reported data have been gathered and analyzed. The objective is to establish whether pre- or post-shredder sorting of plastics of different electrical and electronic equipment, end-of-life vehicle (ELV), textiles and construction waste is necessary to comply with the EU regulations. Particular attention is paid to the recently banned decaBDE and plastics of ELV.

The EU Waste Framework Directive (EU 2018) has set up a separate collection for plastics, and, by January 1, 2025, for textiles. It aims to promote selective demolition in order to enable the establishment of sorting systems for waste construction and demolition, and by extension, for plastic. Waste containing POP substances above concentration limits cannot be landfilled in the EU 2016. Energy recovery as solid recovered fuel must be done in installations fulfilling strict flue gas emission requirements. This paper offers to give some information on the contaminant concentration in plastics and on which type of sorting could be applied for these.

\subsection{Abbreviations}

$\begin{array}{ll}\text { ABS } & \text { Acrylonitrile Butadiene Styrene } \\ \text { ASR } & \text { Automotive shredder residue } \\ \text { BDE } & \text { Bromodiphenylether } \\ \text { BFR } & \text { Brominated flame retardant } \\ \text { CLP } & \text { Classification and Labelling of } \\ & \text { Preparations and Substances } \\ \text { c-pentaBDE } & \text { Commercial pentabromodiphenylether } \\ \text { DBDPE } & \text { Decabromodiphenylethane } \\ \text { DDC-CO } & \text { Dechlorane plus } \\ \text { decaBDE } & \text { Decabromodiphenylether } \\ \text { EDC } & \text { Endocrine disrupting chemicals } \\ \text { EEE } & \text { Electrical and electronic equipment } \\ \text { ELV } & \text { End-of-life vehicle } \\ \text { EPS } & \text { Expanded polystyrene } \\ \text { EU } & \text { European Union } \\ \text { GHS } & \text { United Nations' Globally Harmonized } \\ & \text { System } \\ \text { HBCDD } & \text { Hexabromocyclododecane } \\ \text { heptaBDE } & \text { Heptabromodiphenylether } \\ \text { hexaBDE } & \text { Hexabromodiphenylether }\end{array}$

Hnnn Hazard Statement Code of substances, $\mathrm{H}$ followed by 3-digits number

HP 1 to HP 15 Hazard Property of waste, 1 to 15

ICL Israel Chemical Limited

PBB Polybromobiphenyls

PBDE Polybromodiphenylether

PBT Persistent, bioaccumulative and toxic

PCB Polychlorobiphenyls

pentaBDE Pentabromodiphenylether

PFHxS Perfluorohexanoic acid

PFOA Pentadecafluorooctanoic acid

POP Persistent Organic Polutant

PS Polystyrene

PST Post-shredder treatment

PUR Polyurethane

REACh Registration, Evaluation and Authorization of Chemicals

RoHS Restriction of Hazardous Substances

SCCPs Short chain chlorinated paraffins

TBBPA Tetrabromobisphenol A

tetraBDE Tetrabromodiphenylether

UNEP United Nations Environmental Program

USGS United States Geological Service

VPvB Very persistent and very bioaccumulative

WEEE Waste of electrical and electronic

XPS Extruded polystyrene

\section{REGULATED SUBSTANCES IN PLASTIC MATERIAL (PRODUCTS AND WASTE)}

\subsection{Limitation of concentrations in products}

In electrical and electronic equipment, the following elements and substances are regulated (Directive Restriction of Hazardous Substances (RoHS), EU 2011): cadmium: 100 mg / kg; chromium (VI), mercury, lead: 1000 mg / kg; polybrominated diphenyl ethers (PBDEs): $1000 \mathrm{mg} / \mathrm{kg}$.

In products in general, persistent organic pollutants (POPs) are limited (EU 2016). These substances are defined in the Stockholm Convention as not biodegradable, bioaccumulative and dispersed in the natural environment. Some are prohibited, and actions of emissions reduction must be put in place and monitored (Annex III of EU 2016). The limits in the products are as follows: polychlorinated biphenyls (PCBs): banned from use (Annex III of EU 2016); hexabromocyclododecane (HBCDD): $100 \mathrm{mg} / \mathrm{kg}$ in products subject to review by the Commission by 22/03/2019; hexachlorobutadiene (HCBD): 100 mg / kg (EU 2017a) (not sought here); tetra- or penta- or hexa- or hepta-bromodiphenylethers (PBDE): $1000 \mathrm{mg} / \mathrm{kg}$ when the products are recycled (EU 2016); decabromodiphenylether (decaBDE): 1 000 mg / kg (EU 2017a) after 02/03/2019, with a proposition of the European Parliament as unintentional contaminant of the sum of tetra-, penta-, hexa-, hepta- and decaBDE of $500 \mathrm{mg} / \mathrm{kg}$, and decaBDE of $10 \mathrm{mg} / \mathrm{kg}$ (EP 2019; decided in 2019 to $1000 \mathrm{mg} / \mathrm{kg}$ ); short chain chlorinated paraffins (SCCPs): $10000 \mathrm{mg} / \mathrm{kg}$ (not sought here).

In addition, there are three substances and groups of substances that are currently POP "candidates" (UNEP 2017b): dicofol, pentadecafluorooctanoic acid (PFOA - 
listed in the Stockholm Convention in 2019), its salts and related compounds, and perfluorohexanoic acid (PFHxS), its salts and related compounds. Dicofol is an insecticide (not used in plastics), while PFOA and PFHxS are water-repellent products used, among other things, in vehicle textiles. They were not sought in this study.

Other substances also are a matter of concern. Decabromodiphenylethane (DBDPE) has been reported in WEEE plastics (Wäger et al. 2012, Wäger et al. 2010). Dechlorane plus (abbreviation DDC-CO, CAS No. 13560-89-9), a flame retardant with 12 chlorine atoms, was added to the REACh list of substances that are extremely worrisome (RPA 2014). Dechlorane plus has two isomers (syn- and anti-). It has been found in plastic of vehicles (coarse and fine fractions), as well as in WEEE (Morin et al. 2017). Some data on these substances are reported in this paper.

\subsection{Hazardous waste classification (by hazard prop- erties and POP content)}

For the classification as hazardous waste, the $15 \mathrm{EU}$ hazard properties, HP 1 to HP 15, are defined by the presence or the concentration of substances with specific hazard statement codes (EU 2014a, EU 2017b, EC 2003a). The hazard properties of the relevant substances in plastic waste (with their hazard statement codes from the CLP) for hazard classification are: (i) HP 7 "Carcinogenic", if $\mathrm{Sb}_{2} \mathrm{O}_{3}$ (hazard statement code $\mathrm{H} 351$ 1B) $>10000 \mathrm{mg} / \mathrm{kg}$, equivalent to $\mathrm{Sb}>8354 \mathrm{mg} / \mathrm{kg}$, or if hexabromobiphenyl (H350 1B)> 1000 mg / kg; (ii) HP 10 "Reprotoxic", if hexaor hepta- or octaBDE (H360 1B)> 3000 mg / kg, or if HBCDD (H361)> 30000 mg / kg; (iii) HP 14 "Ecotoxic", if the sum of (tetraBDE, pentaBDE, HBCDD and TBBPA) (H410)> 2500 mg / kg from July 2018 (EU 2014b, EU 2017b) (> 25 $000 \mathrm{mg} / \mathrm{kg}$ before July 2018).

Regarding the POP substances, it should be noted that not all of them can classify a waste as hazardous.

A first group classifies waste as hazardous if the following substances (EU 2016, EU 2014b, EU 2017b) are present at a concentration exceeding a limit. About plastic waste, these substances are in practice (in order of increasing concentration): polychlorinated dibenzo-p-dioxins and dibenzofurans (PCDD / PCDF) $15 \mu \mathrm{g} / \mathrm{kg}$, which can be created unintentionally from RFBs by friction and localized heating of BFRs during waste treatment operations (not sought here); polychlorinated biphenyls (PCBs)> 50 $\mathrm{mg} / \mathrm{kg}$; hexabromobiphenyl (HBB)> $50 \mathrm{mg} / \mathrm{kg}$.

A second group is the POP substances that do not make the waste hazardous because they are classified. However, those wastes must be managed specifically (section 2.4): the PBDEs and the HBCDD. They can trigger the classification as hazardous by their hazard statement codes and their concentrations for the hazard properties HP 4, 5, 10 and 14 , but the classifying concentrations are higher than the ones for specific waste management by their content (s) in POPs (see below).

\subsection{Waste management (by their hazard properties HP)}

Waste can be landfilled if it meets maximum leachable content and total substance levels (EC 2003a, EC 2003b).
In practice, non-hazardous and non-POP plastics can be landfilled in landfills for non-hazardous waste. For hazardous plastic waste, the loss on ignition $(<10 \%)$ or the total organic carbon content (TOC $<6 \%$ ) are exceeded, and these wastes are not allowed to be landfilled in landfills for hazardous waste but must be incinerated. The ashes must meet the criteria for the disposal of hazardous waste, which is possibly the case after a stabilization with cement.

\subsection{Waste management (by their content (s) in POPs)}

The POP substances in waste exceeding the concentration limits of POP regulation for waste (being hazardous or not) must be irreversibly transformed so that the substances no longer have the characteristics of a persistent organic pollutant (EU 2016 Annex IV): polychlorinated dibenzo-p-dioxins and dibenzofurans (PCDD / PCDF) $>15$ $\mu \mathrm{g} / \mathrm{kg}$; polychlorinated biphenyls (PCBs)> 50 mg / kg; hexabromobiphenyl (HBB)> 50 mg / kg; HBCDD< $1000 \mathrm{mg} /$ $\mathrm{kg}$; sum of tetra-, penta-, hexa- and heptaBDE> $1000 \mathrm{mg} /$ $\mathrm{kg}$; and under discussion: sum of tetra-, penta-, hexa-, hepta- and decaBDE> $1000 \mathrm{mg} / \mathrm{kg}$, and a possible lowering two years later to $500 \mathrm{mg} / \mathrm{kg}$ (EP 2019).

These wastes cannot be recycled and must be handled only by the following operations: D9 Physicochemical treatment; D10 Incineration on land and; R1 Main use as fuel or other means of producing energy, excluding wastes containing PCBs.

\subsection{Sorting to separate parts with controlled sub- stance(s) above concentration limits}

For electrical and electronic equipment, polychlorinated biphenyls of capacitors and brominated flame retardants of plastics (among other substances) must be separated (EU 2016). A technical specification (CENELEC CLC/TS 50625-3-1) recommends the sorting of WEEE plastic with a concentration limit of 2000 mg / kg total bromine. In practice, the sorting is carried out either by density (by flotation or by in-line X-ray transmission), or by measurement of bromine (with a portable or in line X-ray fluorescence device).

For products in general, the POPs Regulation (EU 2016) specifies: 'During this elimination or recovery, any substance listed in Annex IV may be isolated from the waste, provided that it is subsequently eliminated...".

\section{REPORTED CONCENTRATION IN PROD- UCTS AND WASTE AND DISCUSSION}

\subsection{Sampling, analysis, reported data}

The reported concentration of BFRs in plastic particles/ parts has a skewed distribution (see section 3.10), with many particles/ parts with nil or low concentration, and a small number of particles/ parts with scattered high concentrations. The principle of sampling is that a smaller (sub-)sample of a flow or a heap will have the same composition as a larger flow or heap if "enough" particles/ parts are taken. The sampling of waste is described in EN 14899 with five technical documents FD CEN/TR 15310-1 to -5 . Considering the skewed distribution of the concentration 
of bromine per plastic scrap and the analytical variability of BFR analysis, it can be calculated EN 14899, EN 15002) that a representative sample should contain 100000 particles (Hennebert 2019). For plastics of WEEE, a technical specification (CENELEC CLC/TS 50625-3-1) recommends the sampling per day of production of the shredder of 10 times 3 litres if the size of the largest particle is $<20 \mathrm{~mm}$, 10 times 5 litres for a particle size of $20-50 \mathrm{~mm}$, and 10 times 10 litres for particle size $>50 \mathrm{~mm}$. The composite sample is coned, mixed and quartered two times (volume divided by 4 ) and $7.5,12$ or 25 litres are sent to the laboratory. The number of particles in these laboratory samples should be checked (Hennebert 2019). The treatment of those samples is described in (EN 15002). The laboratory will cryo-grind it in two or three steps ([10-5] $\mathrm{mm}$ and [1 - <0.1] mm) with an intermediate mixing and quartering steps. An aliquot of $0.1 \mathrm{~g}$ will be extracted thanks to a solvent, and some [0.1-0.01] $\mathrm{ml}$ of the purified extract will be injected in the analysis apparatus (EN 62321-6).

The extraction and analysis of BFR in plastics should be performed by certified industrial laboratories. A publication and a report on ELV plastics vehicles have performed an incomplete extraction of BFR (Table 1). In one case, the samples were crushed at $4 \mathrm{~mm}$ and extracted with an accelerated solvent extractor with toluene at $130^{\circ} \mathrm{C}$ three times (Morin et al. 2017). In the second case, the sample was crushed between 1 and $5 \mathrm{~mm}$ respectively and extracted by cold sonication with hexane for 15 min (SMTT 2012). The extraction yields were not controlled, and the laboratories were not accredited for theses analyses. The measured concentrations in automotive shredder residue are low (Table 1) and those 21 data have not been used in this study. Another case has been reported in car fluff (Norwegian Climate and Pollution Agency 2012).

Published data are heterogeneous. Some are single concentration data, and others are a range of concentration data, with the report of the range values number $(n)$, the minimum (min), the mean (mean), and the maximum (max) of the range. A detailed analysis of these ranges of concentrations cannot be presented here, due to page lim-

TABLE 1: Cases of reported BFR concentrations in plastics of vehicles with presumed incomplete extraction during the laboratory analyses.

\begin{tabular}{|c|c|c|}
\hline Mean concentration $(\mathrm{mg} / \mathrm{kg})$ & $\begin{array}{c}\text { Morin et al. } \\
2017\end{array}$ & $\begin{array}{l}\text { SMMT } \\
2016\end{array}$ \\
\hline DecaBDE & & 3.10 \\
\hline PentaBDEs & & 0.11 \\
\hline HeptaBDEs & & 0.06 \\
\hline TetraBDEs & & 0.04 \\
\hline HexaBDEs & & 0.01 \\
\hline PBDEs & 47.24 & \\
\hline HBCDD (Hexabromocyclododecane) & & 0.565 \\
\hline PBBs (Polybromobiphenyls) & & 0.05 \\
\hline $\begin{array}{l}\text { Sum of PBBs, PBTs (Polybromoter- } \\
\text { phenyls), dechlorane plus anti and syn, } \\
\text { hexabromobenzene, pentabromotolu- } \\
\text { ene and pentabromoethylbenzene }\end{array}$ & 0.36 & \\
\hline
\end{tabular}

itations. The mean concentrations presented here are the mean of all the single concentrations and the min, mean and max concentrations of the ranges. Data reported as " $<$ $x \mathrm{mg} / \mathrm{kg}$ " (lower than the limit of detection or quantification of the laboratory) have been accounted as " $\mathrm{x}$ " $\mathrm{mg} / \mathrm{kg}$. Commercial bromodiphenylethers mixtures (c-BDE) were typically produced at three different degrees of bromination, in particular c-pentaBDE, and are reported as such, aside with pentaBDE. Some authors report the sum of $\mathrm{BDE}$, that were classified POP at the time of their publication (tetra-, penta-, hexa- and hepta-BDE), under the name POP-BDE. PBDE is the sum of all the BDEs data for the same sample. Hexabromocyclododecane (HBCDD) and tetrabromobisphenol A (TBBPA) concentrations are significant and are presented.

Polybrominated biphenyls (PBBs) and polychlorinated biphenyls (PCBs), banned for a long time, have no data for these plastics, and it is known that their concentrations are close to zero in WEEE and automotive plastics (Hennebert and Filella 2017, Hennebert 2018 a, b). Three authors have studied other BFRs. These data are numerous (1440) and briefly presented in section 3.6. A total of 4016 RFBs data and $264 \mathrm{Br}$ and $\mathrm{Sb}$ data were used (total 4280 data) (Table 2). The total number of data sorted by category and by bibliographic reference, for all reported substances and all elements, is presented in Table 3. The reference of the Norwegian Environment Agency - BIPRO (2016) includes of 17 citations other than the ones cited in the References, with less abundant data, and source not fully defined). A partial previous version of this work has been presented as an oral communication (Hennebert 2018b).

In this study, since the distribution of concentrations is never gaussian (normal), the minimum, the median, the mean and the maximum concentrations are presented, as well as the percentage of data exceeding a given (regulatory) concentration.

\subsection{BFRs in electrical and electronic equipment / WEEE}

A total of 962 data (including data of 40 ranges) have been gathered (Table 2). The equipment categories are small and large household (cool/heat, and non cool/heat) equipment, TV, screens, IT equipment, wires, white plastics, and so on, up to a total of 97 different categories. The summarized concentrations are presented in Table 4. No distributions are gaussian (normal): the median concentrations are a smaller fraction of the mean concentrations, and the maximum concentrations are larger multiples of the mean concentrations than in normal distributions (Hennebert 2019). These skewed distributions for the high concentrations are presented with more details in section 3.10. Concentrations $>1000 \mathrm{mg} / \mathrm{kg}$ are highlighted (EC 2003a, EU 2011, EU 2012, EU 2017a).

Large household appliances and cooling and freezing apparatus (two references: Wäger et al. 2012 and Vojta et al. 2017) have a significantly lower concentration of decaBDE than the other equipment (Mann-Whitney test, $p<0.0001$ ), but one reported concentration is equal to the concentration limit of $1000 \mathrm{mg} / \mathrm{kg}$ (Table 5). 
TABLE 2: Total number of data sorted by category from literature, by BFR and element (Br and Sb), and number of data presented in this study ("range data" is reported as a range of concentration, most of the time with the number of the range values, the minimum, the mean and the maximum of the range).

\begin{tabular}{|c|c|c|c|c|c|c|c|c|c|c|c|c|}
\hline \multirow{2}{*}{ 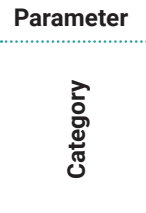 } & \multicolumn{6}{|c|}{ Individual data and range data } & \multicolumn{6}{|c|}{ Number of ranges } \\
\hline & $\sum_{\text {岀 }}^{\text {岃 }}$ & 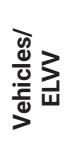 & 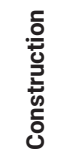 & 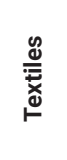 & 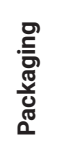 & స్ّ & $\sum_{\text {岀 }}^{\text {岃 }}$ & 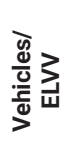 & 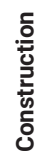 & 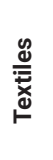 & 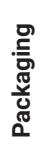 & हึँ \\
\hline \multicolumn{13}{|l|}{ BFRs } \\
\hline PBDE & 781 & 215 & 716 & 437 & & $\begin{array}{l}21 \\
49\end{array}$ & 35 & 26 & 4 & 12 & & 77 \\
\hline $\begin{array}{l}\text { of which } \\
\text { DecaBDE }\end{array}$ & 276 & 80 & 81 & 75 & & $\begin{array}{c}51 \\
2\end{array}$ & & & & & & \\
\hline HBCDD & 112 & 21 & 84 & 59 & 57 & $\begin{array}{c}33 \\
3\end{array}$ & 5 & 2 & 2 & 7 & & 16 \\
\hline TBBPA & 69 & 11 & 6 & & 8 & 94 & & & & & & \\
\hline Sub-total & 962 & 247 & 806 & 496 & 65 & $\begin{array}{l}25 \\
76\end{array}$ & 40 & 28 & 6 & 19 & & 93 \\
\hline $\begin{array}{l}\text { Non-regu- } \\
\text { lated BFRS }\end{array}$ & 257 & 22 & 771 & 374 & 16 & $\begin{array}{l}14 \\
40\end{array}$ & & & & & & \\
\hline Total BFRs & 1219 & 269 & 1577 & 870 & 81 & $\begin{array}{l}40 \\
16\end{array}$ & & & & & & \\
\hline \multicolumn{13}{|l|}{ Elements } \\
\hline $\mathrm{Br}$ & 92 & 36 & 9 & 70 & 6 & $\begin{array}{c}21 \\
3\end{array}$ & 38 & 12 & 3 & 23 & 2 & 78 \\
\hline $\mathrm{Sb}$ & 32 & 11 & 4 & 4 & & 51 & & & & & & \\
\hline $\begin{array}{l}\text { Total } \\
\text { elements }\end{array}$ & 124 & 47 & 13 & 74 & 6 & $\begin{array}{c}26 \\
4\end{array}$ & 38 & 12 & 3 & 23 & 2 & 78 \\
\hline Grand total & 1343 & 316 & 1590 & 944 & 87 & $\begin{array}{l}42 \\
80\end{array}$ & & & & & & \\
\hline
\end{tabular}

\subsection{BFRs in vehicles and end-of-life vehicles}

A total of 247 data (including data of 28 ranges) have been gathered (Table 2). Reported concentrations of brominated flame retardants in cars, automotive shredder residue (ASR), and sorted post shredder treatment fractions (PST fractions) are presented in Table S1 (supplementary information). There are 117 data for Car, 46 data for ELV, 51 for ASR and 33 for PST (total 247 data). The results are indicative since these figures are unweighted means of single data, and min, mean and max of range data. The light fluff fractions are documented as "light ASR" or "mixed light plastic" of the ASR category, or the lighter fractions of the PST category. The PST fractions are sorted by flotation, the most brominated fraction being the densest. PST data treatment fractions are scarce. As a result, data from mixed waste (WEEE and ELV) are also presented for this category. A summary is presented in Table 4.

The discussion will focus on the concentration of decaBDE because this substance is the only one that allows direct comparison between categories (Table 6). Significant mean concentrations are observed in some plastic car parts (rounded mean $3500 \mathrm{mg} / \mathrm{kg}$, above the concentration limit of $1000 \mathrm{mg} / \mathrm{kg}$ ), including printed circuit boards, with the highest concentrations in seats, foam and upholstery $(27000 \mathrm{mg} / \mathrm{kg})$. These high values raise the mean concentration, while the median concentration is only 50 $\mathrm{mg} / \mathrm{kg}$. The sampling of the parts can be biased: authors may have looked for (previously known) parts with high concentration. In some studies, it is a deliberate choice: a multitude of parts are first measured in the field for total bromine with a hand-held X-ray fluorimeter, and only the most concentrated parts are sent to the laboratory for BFRs analyses. But low concentrations are also reported. This peculiar distribution makes it difficult to understand easily this waste flow. Concentrations in ELV are roughly similar to concentrations reported in car parts.

Much lower concentrations are observed in ASR (rounded mean $400 \mathrm{mg} / \mathrm{kg}$ ). The sampling of the ASR is probably not biased: sub-samples are taken at periodic interval from the scrap flow, without previous knowledge of concentration. The median of $44 \mathrm{mg} / \mathrm{kg}$ is comparable to the median of car parts. It is significantly lower than the mean: the distribution is here also skewed by some high values. Lower concentrations than in car parts (see details in Table S1) are probably because plastics and foam are only $20 \%$ of the mass of ASR.

The concentrations in sorted plastics (so-called post-shredder treatment of ASR plastics, here by density separation) are very low (mean $14 \mathrm{mg} / \mathrm{kg}$ ). The effectiveness of sorting (here mainly by density difference) is proven. Details can be found in Leslie et al. (2016). A recent study (Swerea IVF 2018) confirms it for ELV sorted plastics (a French sample of PS/ABS contained $140 \mathrm{mg} / \mathrm{kg}$ decaBDE, and a UK sample of ABS contained $5 \mathrm{mg} / \mathrm{kg}$ decaBDE, $15 \mathrm{mg} / \mathrm{kg}$ TBBPA, and $14 \mathrm{mg} / \mathrm{kg}$ decabromodiphenylethane - DBDPE). 
TABLE 3: Total number of data sorted by category from literature, for all reported substances and all elements.

\begin{tabular}{|c|c|c|c|c|c|c|}
\hline Publication & E & $\mathbf{v}$ & C & $T$ & $\mathbf{P}$ & Total \\
\hline Abdallah et al. 2018 & & & 1 & & 50 & 51 \\
\hline Allen et al. 2008 & 50 & & & 30 & & 80 \\
\hline ARN 2015 & & 1 & & & & 1 \\
\hline Arp et al. 2015 & 67 & 25 & & & & 92 \\
\hline Ballesteros-Gomez et al. 2013 & 4 & & & & & 4 \\
\hline Chen et al. 2010 & 17 & 5 & & & & 22 \\
\hline COWI 2013 & 2 & 2 & & & & 4 \\
\hline Drage et al. 2018 & 60 & 24 & 24 & 60 & & 168 \\
\hline EMPA 2010 & 21 & & & & & 21 \\
\hline Federal office of the Environment (FOEN) 2017 & 33 & & & & & 33 \\
\hline Gallen et al. 2014 & 8 & 3 & & 1 & & 12 \\
\hline Guzzonato et al. 2016 & 93 & & & & & 93 \\
\hline IVM, IVAM 2013 & 43 & 28 & & & & 71 \\
\hline Japanese Ministry of the Environment (MOE) 2011 & & 6 & & & & 6 \\
\hline Jinhui et al. 2017 & 5 & 2 & 2 & 2 & & 11 \\
\hline Kajiwara et al. 2013 & 1 & & & 35 & & 36 \\
\hline Leslie et al. 2016 & 45 & 88 & & 7 & & 140 \\
\hline MEPEX 2012 & & 6 & & & & 6 \\
\hline Morf et al. 2005 & 1 & & & & & 1 \\
\hline Niinipuu 2013 & & 8 & & & & 8 \\
\hline Norwegian Climate and Pollution Agency - Mepex 2012 & & 232 & & & & 232 \\
\hline Norwegian Environment Agency - BIPRO 2016 (17 citations) & 47 & 37 & 4 & 11 & & 99 \\
\hline Petreas et al. 2009 & 12 & 3 & & & & 15 \\
\hline Puype et al. 2015 & 187 & & & & & 187 \\
\hline Rani et al. 2014 & & & 24 & & 32 & 56 \\
\hline RPA 2014 & 6 & 4 & 4 & 4 & & 18 \\
\hline Sindiku et al. 2015 & 4 & & & & & 4 \\
\hline Sinkkonen et al. 2004 & 3 & 3 & & & & 6 \\
\hline Stubbings et al. 2014 & & & & 2 & & 2 \\
\hline Taurino et al. 2010 & 20 & & & & & 20 \\
\hline Turner et al. 2017 Antimony & 4 & 4 & 4 & 4 & & 16 \\
\hline Turner et al. 2017 Bromine & 9 & & 9 & 9 & & 27 \\
\hline Vojta et al. 2017 & 552 & 48 & 1656 & 816 & & 3072 \\
\hline Wäger et al. 2011 & 2 & & & & & 2 \\
\hline Wäger et al. 2012 & 1032 & & & & & 1032 \\
\hline WRc 2012 & 136 & & & & & 136 \\
\hline WRc addendum 2012 & 2 & 18 & & & & 20 \\
\hline Grand total & 2466 & 547 & 1728 & 981 & 82 & 5804 \\
\hline
\end{tabular}

The concentrations are lower than what is reported and observed in the corresponding fractions of WEEE. In France, in unsorted shredded plastics of small household appliances, cathode ray tubes and flat screens, the concentrations were $1950 \mathrm{mg} / \mathrm{kg}$ decaBDE in 2014 and $1395 \mathrm{mg} /$ $\mathrm{kg}$ in 2015 ( $\mathrm{n}=10$ - in triplicates) (Hennebert and Filella 2017). For sorted plastics (fraction $<2000 \mathrm{mg} / \mathrm{kg} \mathrm{Br}$ ), the mean concentrations were $148 \mathrm{mg} / \mathrm{kg}$ decaBDE in 2014 and $522 \mathrm{mg} / \mathrm{kg}$ decaBDE in $2015(\mathrm{n}=4)$.

For elemental concentrations, the most concentrated element is bromine (mean concentration in car parts and ASR = $8564 \mathrm{mg} / \mathrm{kg}, \mathrm{n}=27)$. The concentration used in WEEE for sorting (2 $000 \mathrm{mg} / \mathrm{kg}$, (CENELEC CLC/TS 506253-1) is trespassed. The second most concentrated element 
TABLE 4: Summary of concentration of some brominated flame retardants in plastics of EEE/WEEE, vehicles/ELV, construction, textiles and non-food packaging from literature data, and percentage of data lower and larger than the concentration limit of $1000 \mathrm{mg} / \mathrm{kg}$ (hazardous waste [bold], concentration allowed in products exceeded [underlined], concentration of technical specification for sorting of WEEE plastics $\mathrm{Br}>2000 \mathrm{mg} / \mathrm{kg}$ exceeded [italics]), in yellow: to be sorted for recycling) (in green: lowest \% data per category).

\begin{tabular}{|c|c|c|c|c|c|c|c|c|}
\hline \multirow{2}{*}{ Category } & \multirow{2}{*}{ BFR } & \multicolumn{5}{|c|}{ Concentration data $(\mathrm{mg} / \mathrm{kg})$} & \multirow{2}{*}{$\begin{array}{c}\% \text { data }<1 \\
000 \mathrm{mg} / \mathrm{kg}\end{array}$} & \multirow{2}{*}{$\begin{array}{c}\% \text { data }< \\
500 \mathrm{mg} / \mathrm{kg}\end{array}$} \\
\hline & & $\mathbf{n}$ & Min & Median & Mean & Max & & \\
\hline \multirow[t]{4}{*}{ EEE/WEEE } & PBDE & 781 & 0 & 7 & 2663 & 154000 & $90 \%$ & $87 \%$ \\
\hline & of which DecaBDE & 276 & 0 & 50 & $\underline{5216}$ & $\underline{150000}$ & $84 \%$ & $80 \%$ \\
\hline & HBCDD & 112 & 0 & 200 & 137 & $\underline{1600}$ & $99 \%$ & $99 \%$ \\
\hline & TBBPA & 69 & 20 & 20 & 3155 & 63000 & $93 \%$ & $91 \%$ \\
\hline \multirow[t]{4}{*}{ Vehicles/ELV } & PBDE & 215 & 0 & 6 & 1623 & 85000 & $92 \%$ & $88 \%$ \\
\hline & of which DecaBDE & 80 & 0 & 31 & $\underline{3102}$ & $\underline{85000}$ & $88 \%$ & $78 \%$ \\
\hline & HBCDD & 21 & 0 & 10 & $\underline{386}$ & $\underline{4400}$ & $90 \%$ & $90 \%$ \\
\hline & TBBPA & 11 & 20 & 20 & 27 & 87 & $100 \%$ & $100 \%$ \\
\hline \multirow[t]{4}{*}{ Construction } & PBDE & 716 & 0 & 0 & $\underline{1713}$ & 300000 & $99 \%$ & $99 \%$ \\
\hline & of which DecaBDE & 81 & 0 & 0 & $\underline{8662}$ & 300000 & $95 \%$ & $94 \%$ \\
\hline & HBCDD & 84 & 0 & 0 & $\underline{317}$ & $\underline{10000}$ & $92 \%$ & $89 \%$ \\
\hline & TBBPA & 6 & 0 & 0 & 0 & 0 & $100 \%$ & $100 \%$ \\
\hline \multirow[t]{4}{*}{ Textiles and upholstery } & PBDE & 437 & 0 & 0 & 2080 & 130000 & $95 \%$ & $94 \%$ \\
\hline & of which DecaBDE & 75 & 0 & 0 & $\underline{6511}$ & $\underline{120000}$ & $84 \%$ & $81 \%$ \\
\hline & HBCDD & 59 & 0 & 0 & $\underline{3465}$ & $\underline{51000}$ & $86 \%$ & $86 \%$ \\
\hline & TBBPA & - & - & - & - & - & - & - \\
\hline \multirow[t]{4}{*}{ Non-food Packaging } & PBDE & - & - & - & - & - & - & - \\
\hline & of which DecaBDE & - & - & - & - & - & - & - \\
\hline & HBCDD & 57 & 0 & 11 & $\underline{232}$ & $\underline{5897}$ & $91 \%$ & $88 \%$ \\
\hline & TBBPA & 8 & 0 & - & 0 & 1 & - & - \\
\hline
\end{tabular}

TABLE 5: Concentration of decaBDE in large household appliances and other categories of EEE/WEEE from literature data (concentration allowed in products exceeded [underlined]).

\begin{tabular}{l|c|cccc} 
DecaBDE $(\mathbf{m g} / \mathbf{k g})$ & $\mathbf{n}$ & Minimum & Median & Mean & $\begin{array}{l}\text { Maximum } \\
\text { deviation }\end{array}$ \\
\hline $\begin{array}{l}\text { Large household appliances, } \\
\text { cooling and freezing appliances }\end{array}$ & 36 & 0 & 50 & 84 & 1000 \\
\hline Other categories & 240 & 0 & 50 & $\underline{5985}$ & $\underline{150000}$ \\
\hline
\end{tabular}

is lead (mean concentration in car parts $=6499 \mathrm{mg} / \mathrm{kg}, \mathrm{n}$ = 13) (result not shown, Hennebert 2018a). The concentration of the Restriction of Hazardous Substances (RoHS)

TABLE 6: Concentrations of decaBDE in car parts, automotive shredder residue (ASR) and post shredder treatment fractions unweighted mean concentrations and median from literature data (concentration allowed in products exceeded [underlined], concentration of technical specification for sorting of WEEE plastics $\mathrm{Br}$ > $2000 \mathrm{mg} / \mathrm{kg}$ exceeded [italics]).

\begin{tabular}{l|c|c|c}
\hline Concentration (mg/kg) & \multicolumn{3}{|c}{ DecaBDE } \\
\hline Category & Mean & Median & $\mathbf{n}$ \\
\hline Car - parts & $\underline{3469}$ & 50 & 35 \\
\hdashline ASR & 386 & 44 & 21 \\
\hdashline PST - sorted plastics & $(101)$ & $(6)$ & $(11)$ \\
\hline $\begin{array}{l}\text { Of automotive shredder } \\
\text { residue }\end{array}$ & 14 & 3 & 6 \\
\hline $\begin{array}{l}\text { (Of mixed automotive and } \\
\text { WEEE shredder residue) }\end{array}$ & $(205)$ & $(29)$ & 5 \\
\hline
\end{tabular}

(EU 2011) applicable to EEE is trespassed (1 $000 \mathrm{mg} /$ $\mathrm{kg}$ ). According to some authors, it is due to printed circuit boards soldering.

\subsection{BFRs in construction plastics}

In total, 806 data (including data from 6 ranges) were collected (Table 2). The various samples are presented in Table S2 by group of BFR present or not (last column) and by decreasing mean concentration. The distinction between the PBDE - decaBDE groups on the one hand and HB$\mathrm{CDD}$ on the other hand is very clear, with more foams and polystyrenes for the latter group. However, HBCDD concentrations are too low to be flame retardant: the maximum is $0.54 \%$, while 0.8 to $4 \%$ is recommended (Arias 2001, Alaee et al. 2003). This may be the index of products derived from recycling a mixture of brominated and non-brominated plastics . The RFB-free group includes paint, wood panels, paper-based insulation, etc. A summary is presented in Table 4. The samples from continental Europe (69 out of 
85 samples) have low to very low concentrations (results not shown).

\subsection{BFRs in textile equipment}

A total of 496 data (including data from 19 ranges) were collected (Table 2). Plastics also cover a wide range (0-300 $000 \mathrm{mg} / \mathrm{kg}$-Table S3) presented by group of BFR present or not (last column) and by decreasing average concentration. A first PBDE - decaBDE group without HBCDD can be identified, mostly with non - flame retardant concentrations (at least $5 \%$ according to Arias 2001, Alaee et al. 2003). A second and smaller group contains HBCDD with or without PBDEs. The group without BFR is made up of articles that do not seem different from the first two groups.

A summary of concentrations for all samples is presented in Table 43. The average concentration of decaBDE is of $6500 \mathrm{mg} / \mathrm{kg}(\mathrm{n}=75)$, which is above the limit for the products. This result is consistent with the high level observed in automotive seats and foams (Hennebert 2018a, this paper). The average HBCDD concentration is hazardous and above the limit for the products. The plastics of textile equipment should therefore be sorted. Here also, the samples from continental Europe (36 out of 55) have low to very low concentrations (results not shown).

\subsection{BFRs in non-food packaging}

In total, 65 data (without data ranges) were collected (Table 2). These plastics are exclusively expanded polystyrene (EPS) and extruded polystyrene (XPS) with HBCDD as RFB. The concentrations are presented in Table 4. Concentrations are low, but 31 samples have a HBCDD concentra- tion> $10 \mathrm{mg} / \mathrm{kg}$, the highest being polystyrene packaging laboratory equipment, appliances and printers (Abdallah et al. 2018, FOEN 2017). The maximum HBCDD content exceeds the concentration limit for hazardous waste, and the average is greater than what is allowed for the products. These plastics should therefore be sorted.

\subsection{BFRs in food-contact packaging}

This point is not the focus of this study but is however presented since, according to some authors, there is evidence of recycling of brominated plastics (maybe from construction insulation foams) in food-contact articles. According to two authors (Rani et al. 2014, Abdallah et al. 2018), six data out of 66 of disposable plate and cup, menu box, takeaway food container, PS cold box, vegetable packaging, and similar, all in expanded polystyrene or extruded polystyrene, have a concentration of HBCDD $>10$ $\mathrm{mg} / \mathrm{kg}(1516,50,29,15,14$ and $10 \mathrm{mg} / \mathrm{kg})$. This indicates the usefulness of sorting EPS and XPS (particularly from construction plastics) for bromine and BFRs.

\subsection{Other BFRs}

Three authors (Rani et al. 2014, Abdallah et al. 2018, FOEN 2017) measured 12 unregulated RFBs nowadays (Table 7) on a total of 144 samples. Only the maximum concentrations are presented. The concentrations are low or close to zero. For e-waste, the highest concentrations are reported by (FOEN 2017). Decabromodiphenylethane (DBDPE) has been a substitute for decaBDE for two decades in plastics of EEE (Wäger et al. 2012). For construction plastics, a rubber sample and a recycled plastic material sample have a dechlorane concentration greater than $64 \mathrm{mg} / \mathrm{kg}$ and $17 \mathrm{mg} / \mathrm{kg}$, respectively (Vojta et al. 2017).

TABLE 7: Maximum concentrations in non-regulated RFBs.

\begin{tabular}{|c|c|c|c|c|c|c|c|c|}
\hline \multicolumn{3}{|c|}{ Maximum concentration (mg/kg) } & \multicolumn{6}{|l|}{ Category } \\
\hline Abbreviation & Name & CAS No & EEE/WEEE & $\begin{array}{l}\text { Vehicles/ } \\
\text { ELV }\end{array}$ & $\begin{array}{l}\text { Construc- } \\
\text { tion }\end{array}$ & Textiles & $\begin{array}{l}\text { Non-food } \\
\text { packaging }\end{array}$ & $\mathbf{n}$ \\
\hline BTBPE & $\begin{array}{l}\text { 1,2-Bis(2,4,6-tribromophenoxy) } \\
\text { ethane }\end{array}$ & $37853-59-1$ & 150 & 0 & 1 & 0 & 0 & 144 \\
\hline DBDPE (DBDPER) & $\begin{array}{l}\text { Decabromodiphenylethane } \\
\text { or 1,2-bis(pentabromodiphenyl) } \\
\text { ethane }\end{array}$ & $84852-53-9$ & 340 & & 0 & & 0 & 15 \\
\hline DBE-DBCH (TBECH) & $\begin{array}{l}\text { Tetrabromoethylcyclohexane } \\
\text { (sum of alpha- and beta-) }\end{array}$ & $3322-93-8$ & 0 & 0 & 0 & 0 & & 128 \\
\hline DBHCTD (HCDBCO) & $\begin{array}{l}\text { Hexachlorocyclopentenyl-dibro- } \\
\text { mocyclooctane }\end{array}$ & 51936-55-1 & 0 & 0 & 0 & 1 & & 128 \\
\hline DDC-CO & $\begin{array}{l}\text { Dechlorane Plus (sum of anti- } \\
\text { and syn-) }\end{array}$ & $13560-89-9$ & 33 & 0 & 64 & 1 & & 129 \\
\hline HBB & Hexabromobenzene & $87-82-1$ & 0 & 0 & 1 & 1 & & 128 \\
\hline PBEB & Pentabromoethylbenzene & $85-22-3$ & 0 & 0 & 0 & 0 & & 128 \\
\hline PBT & Pentabromotoluene & $87-83-2$ & 0 & 0 & 0 & 0 & & 128 \\
\hline TBCO & $\begin{array}{l}\text { 1,2,5,6-Tetrabromocyclooctane } \\
\text { (sum of alpha- and beta-) }\end{array}$ & $3194-57-8$ & 0 & 0 & 0 & 0 & & 128 \\
\hline TBP-BAE (BATE) & $\begin{array}{l}\text { 2-Bromoallyl-2,4,6-tribromophe- } \\
\text { nyl ether }\end{array}$ & $3728-89-5$ & 0 & 0 & 0 & 0 & & 128 \\
\hline TBP-DBPE (DPTE) & $\begin{array}{l}\text { 2,3-Dibromopropyl-2,4,6-tribro- } \\
\text { mophenyl ether }\end{array}$ & $35109-60-5$ & 0 & 0 & 0 & 0 & & 128 \\
\hline TBX (pTBX) & 2,3,5,6-Tetrabromo-p-xylene & 23488-38-2 & 0 & 0 & 0 & 0 & & 128 \\
\hline Total & & & 340 & 0 & 64 & 1 & 0 & 1440 \\
\hline
\end{tabular}




\subsection{Total $\mathrm{Br}$ and $\mathrm{Sb}$ in plastics}

A total of 265 data (including data of 78 ranges) have been gathered (Table 8 ). All these plastics are brominated to some extent, the highest being the EEE/WEEE plastics, followed by vehicles/ELV and textiles plastics, and then with lower concentrations construction plastics and nonfood packaging plastics. The WEEE technical specification (CENELEC CLC/TS 50625-3-1) recommends the sorting of plastics batches or flows with mean concentration of total $\mathrm{Br}>2000 \mathrm{mg} / \mathrm{kg}$ (measured on a representative laboratory sample). If applied to other plastics, the first four categories of Table 8 should be sorted.

These plastics also contain antimony. Two plastic samples are classified as hazardous based on their concentration of antimony (in bold): "construction - plumbing" at 13 $000 \mathrm{mg} \mathrm{Sb} / \mathrm{kg}$ and "dressing - padding" at $9922 \mathrm{mg} \mathrm{Sb} / \mathrm{kg}$.

\subsection{Synthesis of regulated BFRs concentrations and distribution of concentration}

The 2576 data from the literature summarized in Table 4 indicate that the five categories of plastics studied always have at least one BFR at medium or maximum concentration classified hazardous, not allowing the recycling of the products, or having a total bromine content> $2000 \mathrm{mg} /$ $\mathrm{kg}$, and therefore not recyclable without sorting. A large majority of the data is lower than $1000 \mathrm{mg} / \mathrm{kg}$ or $500 \mathrm{mg} /$ $\mathrm{kg}$. Some distributions are illustrated in Figure 1. The interval of concentration in the histograms is $1000 \mathrm{mg} / \mathrm{kg}$. The first interval of concentration [0-1 000] mg/kg has been set to the concentration limit for unintentional (re)use in products. The distributions of data are skewed by large values, as illustrated by the significant differences between the median and the mean (Table 4). The same distribution applies to individual scraps (Hennebert 2019). If the last percentiles of scraps are sorted out, the mean concentration falls drastically, and these plastics can therefore be recycled.

\section{MANAGEMENT OPTIONS}

For plastic recycling, the so-called "brominated fraction" should be separated, either by sorting for total bromine by $X$-ray transmission on line, or by flotation in a bath with a different density, as practiced today for WEEE (Hennebert and Filella 2017, Leslie et al. 2016, Swerea IVF 2018).

The POP fractions above the concentration limits should be destroyed in incinerators or irreversibly transformed (EU
2016). The incinerators must fulfil the emissions requirements of (chloro- and bromo-) dioxins and furans in the flue gas, and of leachable antimony $\left(\mathrm{Sb}_{2} \mathrm{O}_{3}\right.$ is used as a synergist of BFRs in plastics) in the ashes and in the air pollution control residue. Corrosion of the installation by bromine is intense (Buekens and Zhou 2014). Bromine is present partly as $\mathrm{HBr}$ and partly as elemental bromine $\mathrm{Br}_{2}$ (g). $\mathrm{HBr}$ is easily neutralized by solid sodium bicarbonate or captured by wet scrubbing with sodium hydroxide, but not $\mathrm{Br}_{2}$. If not destroyed, POP substances will continue their cycle (Norwegian Climate and Pollution Agency 2012, Leslie et al. 2016). POP substances are found in landfill leachate (Morin et al. 2017). Traces of BFRs have been found in food-contact articles (Puype et al. 2015), together with rare earth elements from electronic goods. Large reviews point out the ubiquity of these substances (Norwegian Environment Agency 2015, 2016, 2017). These legacy substances can hamper the achievement of the compulsory objective of recycling in the EU. This point has been well identified by the European Commission (EC 2017). Finland has suggested that the EU recycling targets for ELV (85\% of recycling including scraps and $10 \%$ energy recovery) be calculated from the material left after removal of hazardous substances and components (specified in Annex VII of the WEEE Directive 2012/19/EU) (Häkkinen 2016).

The "brominated plastics" are today mainly incinerated in incinerators for hazardous waste, in cement kiln, or in non-ferrous smelters refineries, with special management for corrosion by bromine, for the emission of elemental bromine and brominated dioxins / furans in the fumes, and for the presence of leachable antimony in the ashes, slags and air pollution control residues (Norwegian Environment Agency 2017). A non-ferrous smelter, Umicore, claims $70 \%$ recovery of $\mathrm{Sb}$, a critical raw material, according to the EU and the USGS. If the POP concentration limit is not exceeded, they could theoretically be reused as flame-retarded plastics. But in practice, they are refused by manufacturers who have developed precise formulated compounds. They are mainly used as solid recovered fuel (emissions in the fumes should be secured) or landfilled in landfills for non-hazardous waste. For instance, in France, $40 \%$ of the ELV plastics are burned in different installations and $29 \%$ are landfilled (Deloitte and ADEME 2017).

Chemical recycling by cracking of plastics or solvolysis is up till now hampered by the incomplete separation of brominated compounds from the useful un-brominated

TABLE 8: Concentration of total $\mathrm{Br}$ and $\mathrm{Sb}$ in plastics of EEE/WEEE, vehicles/ELV, construction, textiles and non-food packaging from literature data (hazardous waste [bold], concentration of technical specification for sorting of WEEE plastics Br> $2000 \mathrm{mg} / \mathrm{kg}$ exceeded [italics]).

\begin{tabular}{|c|c|c|c|c|c|c|c|c|c|c|}
\hline \multirow{2}{*}{ Plastics } & \multicolumn{5}{|c|}{$\mathrm{Br}$} & \multicolumn{5}{|c|}{ Sb } \\
\hline & $\mathbf{n}$ & Min & Median & Mean & Max & $\mathbf{n}$ & Min & Median & Mean & Max \\
\hline EEE/WEEE & 92 & 0 & 145 & 13374 & 171000 & 32 & 0 & 1000 & 3381 & 58900 \\
\hline Vehicles/ELV & 36 & 0 & 314 & 8197 & 106800 & 11 & 34 & 975 & 1521 & 6020 \\
\hline Construction & 9 & 0 & 45 & 2122 & 9410 & 4 & 103 & 984 & 3768 & 13000 \\
\hline Textiles and upholstery & 70 & 0 & 99 & 7175 & 128300 & 4 & 90 & 944 & 2975 & 9922 \\
\hline Packaging & 6 & 0 & 10 & 1153 & 5600 & - & - & - & - & - \\
\hline
\end{tabular}



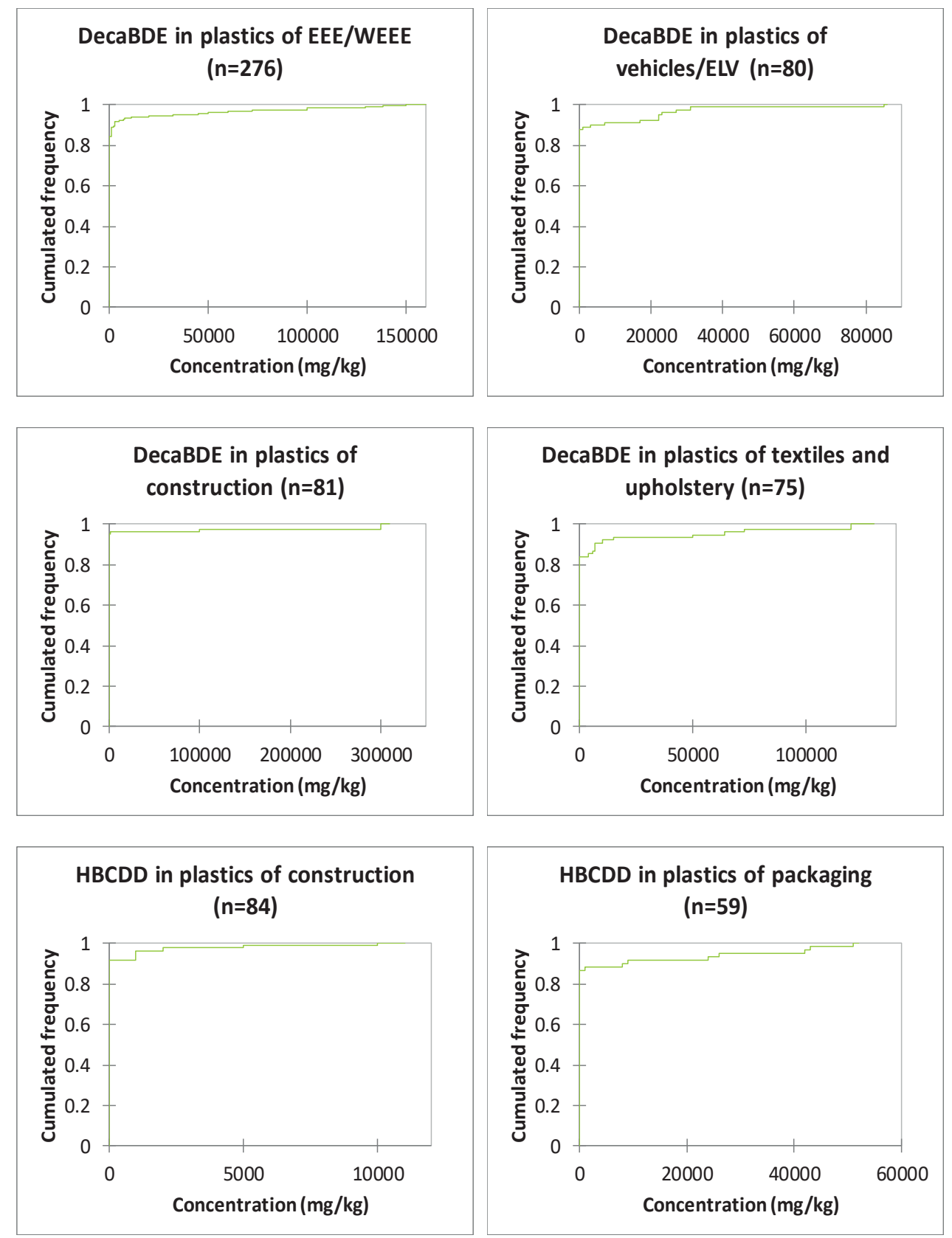

FIGURE 1: Distribution of decaBDE concentrations in plastics of EEE, vehicles, construction and textiles, and of HBCDD in expanded polystyrene foam of non-food packaging from literature data (frequency of data per concentration class of $1000 \mathrm{mg} / \mathrm{kg}$ ).

feedstock chemicals. The production of syngas or liquid fuel by pyrolysis (heating without oxygen) faces the same obstacle. Exportation is in practice restricted since China decided in January 2018 to stop the importation of unsorted or contaminated plastics. Following others, a pyrolysis technology with recovery of heat, bromine and antimony is claimed at pilot scale in 2018 (Hense et al. 2018). A short synthesis of the advantages and drawbacks of the different management options is presented in Table 9.

\section{CONCLUSION}

The EU plastics strategy in a circular economy stipulates that plastics containing regulated BFRs must be sorted and managed separately from the non-brominated fraction. Sorting is essential to avoid the uncontrolled dispersion of controlled substances in recycled raw materials.

According to the EU, regulations are in force for each category. These unsorted plastics are hazardous (average or maximum for a BFR), they cannot be reincorporated as such into products, and they exceed $2000 \mathrm{mg} \mathrm{Br} / \mathrm{kg}$ (operational sorting concentration for WEEE plastics). This study shows that approximately $16 \%, 12 \% 8 \%, 16 \%$ and $9 \%$ of published concentrations of plastics from EEE/WEEE, vehicles/ELV, building materials, textile equipment and non-food packaging could be greater than $1000 \mathrm{mg} / \mathrm{kg}$ of regulated RFBs. Overall, the results indicate that the sorting 
TABLE 9: Management options of brominated and antimoniated plastics.

\begin{tabular}{|c|c|c|c|c|c|c|c|c|c|c|c|c|c|}
\hline 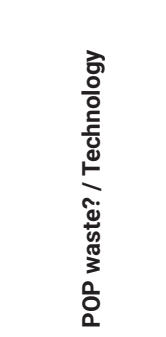 & 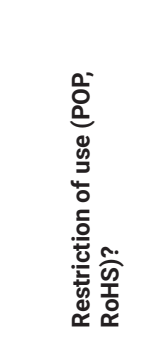 & 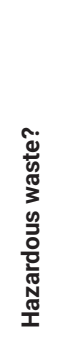 & 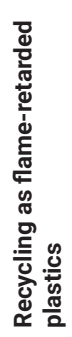 & 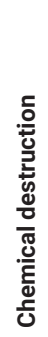 & 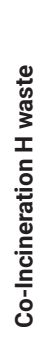 & 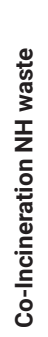 & 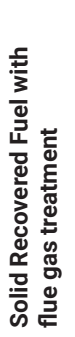 & 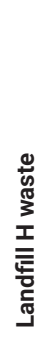 & 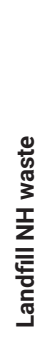 & 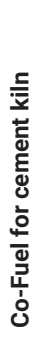 & 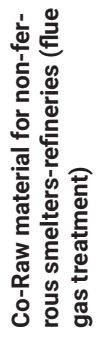 & 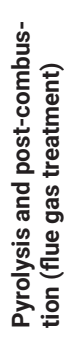 & $\begin{array}{l}\text { t늠 } \\
\text { வ }\end{array}$ \\
\hline \multicolumn{14}{|l|}{ Classification } \\
\hline Yes & - & - & & $x$ & $x$ & & & & & $?$ & $?$ & & \\
\hline \multirow[t]{4}{*}{ No } & Yes & Yes & $\mathrm{x}$ & & & $x$ & $\mathrm{x}$ & $X ?$ & & $x$ & $x$ & & \\
\hline & & No & $x$ & & & $x$ & $\mathrm{x}$ & & $x$ & $x$ & $x$ & & \\
\hline & No & Yes & $x$ & & & $x$ & $\mathrm{x}$ & & $x$ & $\mathrm{x}$ & $\mathrm{x}$ & & \\
\hline & & No & $x$ & & & $x$ & $x$ & & $x$ & $x$ & $x$ & & $\mathrm{x}$ \\
\hline \multicolumn{14}{|l|}{ Technology } \\
\hline \multirow[t]{7}{*}{ Recovery } & Polymer & & & & & & & & & & & & \\
\hline & Heat & & & & $x$ & $x$ & $x$ & & & $x$ & $x$ & & \\
\hline & Oil & & & & & & & & & & & $\mathrm{x}$ & \\
\hline & Gas & & & & & & & & & & & $x$ & \\
\hline & $\mathrm{Br}$ & & & & & & & & & & $\mathrm{HBr}$ ? & & \\
\hline & $\mathrm{Sb}$ & & & & & & & & & & $70 \%$ & & \\
\hline & $\begin{array}{l}\text { Metals of } \\
\text { non-plastics }\end{array}$ & & & & & & & & & & $x$ & $x$ & \\
\hline \multirow[t]{5}{*}{ Drawbacks } & C content & & & & & & & $x$ & & & & & \\
\hline & $\mathrm{Br} 2 \mathrm{gas}$ & & & & $\mathrm{x}$ & $x$ & $x$ & & & $x$ & $x$ & $x$ & \\
\hline & Leach. Sb & & & & $\mathrm{x}$ & $\mathrm{x}$ & $\mathrm{x}$ & & & $?$ & $30 \% ?$ & $\mathrm{x}$ & \\
\hline & Leach. POP & & & & & & & $\mathrm{x}$ & $\mathrm{x}$ & & & & \\
\hline & Corrosion & & & & $\mathrm{x}$ & $\mathrm{x}$ & $\mathrm{x}$ & & & $\mathrm{x}$ & $\mathrm{x}$ & $\mathrm{x}$ & \\
\hline \multirow{4}{*}{$\begin{array}{l}\text { Technology } \\
\text { Maturity level }\end{array}$} & Routine & & & & $\mathrm{x}$ & $\mathrm{x}$ & $\mathrm{x}$ & & $\mathrm{x}$ & $\mathrm{x}$ & $\mathrm{x}$ & & $x$ \\
\hline & $R \& D$ & & & & & & & & & & & $x$ & \\
\hline & Laboratory & & $x$ & $x$ & & & & & & & & $\mathrm{x}$ & \\
\hline & Not practiced & & $x$ & $x$ & & & & $x$ & & & & $x$ & \\
\hline
\end{tabular}

of bromine content for these categories of plastics (except for food packaging) is necessary.

Literature also shows that sorting is effective: data are scarce but sorted ELV plastics have a mean decaBDE concentration of $14 \mathrm{mg} / \mathrm{kg}$. The efficiency of sorting was confirmed in France with WEEE plastics in 2014 and 2015 (Hennebert and Filella 2017). As the plastics of construction and demolition waste must be sorted in the EU and that separate collection of textiles is foreseen at the latest in 2025 (EU 2018), all these plastics (excepted food-packaging) will have to be sorted to weed out regulated substances (PBDE, HBCDD) in a circular economy. The amount to be sorted could reach $40 \%$ of the amount of plastics used in the EU, representing 20 million of tons per year (calculated from PlasticsEurope 2018). The amount that could not be recycled is a few percent of that mass. It must be emphasized that the samples of construction plastics and textile and furniture plastics from continental Europe have low to very low concentrations.

To conclude, it should be checked by analytical campaigns whether the different (sorted) plastics fractions have a POP waste status or not, and whether the major actual management practices of energy recovery and landfilling are in line with the EU regulations. Research in technology to recover energy, bromine and antimony is active and promising on a pilot scale.

\section{ACKNOWLEDGEMENTS}

This work was carried out as part of Ineris' support work on behalf of the Ministry of the Environment, France. Ms. Pauline Molina is warmly thanked as well for the building of the first part of this study database.

\section{REFERENCES}

Abdallah, M. A., M. Sharkey, et al. (2018). "Hexabromocyclododecane in polystyrene packaging: A downside of recycling?" Chemosphere 199: 612-616.

Alaee, M., Arias, P., Sjodin, A., Bergman, A. (2003). An overview of commercially used brominated flame retardants, their applications, their use patterns in different countries/regions and possible modes of release. Environ. Int. 29, 683-689. 
Albemarle 2018. Albemarle 2018. Fire Safety Solutions - Product Selector Guide. www.albemarle.com . Consulted Jan 2018.

Arias P. 2001. Brominated flame retardants-an overview. The Second International Workshop on Brominated Flame Retardants. Stockholm: AB Firmatryck, 2001. p. 17- 9.

Arp, H.P.H., Morin, N.A.O., Hale, S.E., Okkenhaug, G., Breivik, K., Sparrevik, M., 2017. The mass flow and proposed management of bisphenol A in selected Norwegian waste streams. Waste Manag. 60, 775-785. https://doi.org/10.1016/j.wasman.2017.01.002

Auto Recycling Netherlands (ARN Recycling BV) (2015). Turning waste into raw materials - ELV automotive plastics recycling

Ballesteros-Gómez, A., Brandsma, S.H., De Boer, J., Leonards, P.E.G. 2014. Direct probe atmospheric pressure photoionization/atmospheric pressure chemical ionization high-resolution mass spectrometry for fast screening of flame retardants and plasticizers in products and waste. Anal. Bioanal. Chem. 406, 2503-2512. https://doi.org/10.1007/s00216-014-7636-8

Buekens A, Zhou X (2014). Recycling plastics from automotive shredder residues: a review. J Mater Cycles Waste Manag (2014) 16:398-414.

CEN FD CEN/TR 15310-1 to -5:2007. Characterization of waste - Sampling of waste material. CEN, Brussels, Belgium

CENELEC CLC/TS 50625-3-1:201.5 Requirements for collection, logistics and processing for Waste Electrical and Electronic Equipment (WEEE) - Part 3-1: Specifications for depollution. CENELEC, Brussels, Belgium.

Chemtura Great lakes Solution (2018). Great Lakes Solution 2017. LANXESS Bromine Solutions. Flame retardants product guide. Consulted Jan 2018.

Chen S.J., Ma Y.J., Wang J., Tian M., Luo X.J., Chen D., Mai B.X. (2010). Measurement and human exposure assessment of brominated flame retardants in household products from South China. Journal of Hazardous Materials, 176

COWI (consulting company) (2014). End-of-Life vehicles and environmental pollutants in material flows at shredder plants - An overview. Trondheim, Norway, COWI.

Deloitte and ADEME (2017). Deloitte Développement Durable (Salès K, Lornet L, Benhallam R.) and ADEME (Lecointre E). Octobre 2017. Rapport Annuel de l'Observatoire des Véhicules Hors d'Usage Données 2015. 118 pages.

Drage, D.S., Sharkey, M., Abdallah, M.A.E., Berresheim, H., Harrad, S., 2018. Brominated flame retardants in Irish waste polymers: Concentrations, legislative compliance, and treatment options. Sci. Total Environ. 625, 1535-1543. https://doi.org/10.1016/j.scitotenv.2018.01.076

EC 2003a. Directive 2003/11/EC of the European Parliament and of the Council of 6 February 2003 amending for the 24th time Council Directive 76/769/EEC relating to restrictions on the marketing and use of certain dangerous substances and preparations (pentabromodiphenyl ether, octabromodiphenyl ether). OJEU 15.2.2003 L $42 / 45$

EC 2003b. Council Decision of 19 December 2002 establishing criteria and procedures for the acceptance of waste at landfills pursuant to Article 16

EC 2011. European Commission. Service request under the framework contract No ENV.G.4/FRA/2007/0066. Final report "Study on waste related issues of newly listed POPs and candidate POPs" 25 March 2011 (Update 13 April 2011). Consortium ESWI Expert Team to Support Waste Implementation. by Umweltbundesamt, Bipro, Enviroplan. 841 p. http://ec.europa.eu/environment/waste/ studies/pdf/POP_Waste_2011.pdf

EC 2017. Strategy on Plastics in a Circular Economy. 26/01/2017. 4 p.

EN 14899:2015. Characterization of Waste - Sampling of waste materials - Framework for the preparation and application of a Sampling Plan. CEN, Brussels, Belgium

EN 15002:2015. Characterization of waste - Preparation of test portions from the laboratory sample. CEN, Brussels, Belgium

EN 62321-6: 2015. Determination of certain substances in electrotechnical products - Part 6: polybrominated biphenyls and polybrominated diphenyl ethers in polymers by gas chromatography-mass spectrometry (GC-MS). CEN, Brussels, Belgium

EP 2019. European Parliament legislative resolution of 18 April 2019 on the proposal for a regulation of the European Parliament and of the Council on persistent organic pollutants (recast) (COM(2018)0144 - C8-0124/2018 - 2018/0070(COD)). http://www.europarl.europa. eu/doceo/document/TA-8-2019-0436_EN.html
EU 2011. Directive 2011/65 of the European Parliament and of the Council of 8 June July 2011 on the restriction of the use of certain hazardous substances (RoHS) in electrical and electronic equipment (recast). Official Journal of the European Union, L174, 1.7.2011, p 88-110.

EU 2012. Directive 2012/19/EU of the European Parliament and of the Council of 4 July 2012 on waste electrical and electronic equipment (WEEE) (recast). Official Journal of the European Union 24.7.2012. L 197/38.

EU 2014a. Commission Decision 2014/955/EU of 18 December 2014 amending Decision 2000/532/EC on the list of waste pursuant to Directive 2008/98/EC of the European Parliament and of the Council. http://eurlex.europa.eu/legalcontent/EN/TXT/PDF/?uri=CELEX:32014D0955\&rid=1

EU 2014b. Commission Regulation (EU) No 1357/2014 of 18 December 2014 replacing Annex III to Directive 2008/98/EC of the European Parliament and of the Council on waste and repealing certain Directives. Official Journal of the European Union. 19.12.2014. L 365/89.

EU 2016. Regulation (EC) No 850/2004 of the European parliament and of the Council of 29 April 2004 on persistent organic pollutants(POP) and amending Directive 79/117/EEC. Official Journal of the European Union, L 158, p. 7, 30.4.2004, last amended Commission Regulation (EU) 2016/460 of 30 March 2016, Official Journal of the European Union, L 80, p. 17, 31.3.2016.

EU 2017a. Commission Regulation (EU) 2017/227 of 9 February 2017 amending Annex XVII to Regulation (EC) No 1907/2006 of the European Parliament and of the Council concerning the Registration, Evaluation, Authorisation and Restriction of Chemicals (REACH) as regards bis(pentabromophenyl)ether. Official Journal of the European Union. L35/6. 10.2.2017

EU 2017b. Council Regulation (EU) 2017/997 of 8 June 2017 amending Annex III to Directive 2008/98/EC of the European Parliament and of the Council as regards the hazardous property HP 14 'Ecotoxic'. Official Journal of the European Union. 14.6.2017. L 150/1.

EU 2018. Directive (EU) $2108 / 851$ of the European Parliament and of the Council of 30 May 2018 amending Directive 2008/98/EC on waste. Official Journal of the European Union. 14.6.2018. L 150/109. $32 \mathrm{p}$

Federal Office for the Environment FOEN (2017). Substance flows in Swiss e-waste - Metals, non-metals, flame retardants and polychlorinated biphenyls in electrical and electronic devices. Bern, 2017. 8 p. Summary of the publication "Stoffflüsse im Schweizer Elektronikschrott" www.bafu.admin.ch/uz-1717-d

Galloway T S, Lee B P, Buric I, Steele A M, BPA Schools Study Consortium, Kocur A L, Pandeth A G, Harries L W. 2019. Plastics Additives and Human Health: A Case Study of Bisphenol A (BPA). Issues in Environmental Science and Technology 2019(47):131-155

Groh K J, Backhaus T, Carney-Almroth B, Geueke B, Inostroza P A, Lennquist A, Leslie H A, Maffini M, Slungef D, Trasande L, Warhurst A M Muncke J. 2019. Overview of known plastic packaging-associated chemicals and. their hazards. Science of the Total Environment 651 (2019) 3253-3268

Hahladakis J N, Velis C A, Weber R, lacovidou E, Purnell P. 2018. An overview of chemical additives present in plastics: Migration, release, fate and environmental impact during their use, disposal and recycling. Journal of Hazardous Materials 344 (2018) 179-199

Häkkinen E. (2016). Finnish Guidance on POPs waste and pre-treatment of ELVs. Finnish Environment Institute. 22 November 2016, ppt 12 slides. Project on development of the environmental protection of transport, storage and pre-treatment operations of ELVs (Project report published in January 2016), Guidance on management of POPs waste (Published in September 2016).

Hennebert P, Filella M. (2017). WEEE plastic sorting for bromine essential to enforce EU regulation. Waste Management, 71, January 2018, 390-399.

Hennebert P. (2018a). Concentrations of brominated flame retardants in plastics of electrical and electronic equipment, vehicle, textiles and construction: a short review of occurrence and management. Proceedings of the 6th International Conference on Industrial and Hazardous Waste Management. Chania (Greece). 04-07/09/2018. $13 \mathrm{p}$.

Hennebert P. (2018b). Revue bibliographique des concentrations en substances réglementées dans les plastiques de véhicules hors d'usage. Rapport INERIS DRC-18-173977-02943B. 18/12/2018. 56 p. 
Hennebert P. (2019). Sorting of waste for circular economy: sampling when (very) few particles have (very) high concentrations of contaminant or valuable element (with bi- or multi-modal distribution). 17th International Waste Management and Landfill Symposium (Sardinia 2019), 30/09 - 04/10/2019, Cagliari, Italy

Hense P, Aigner J, Franke M, Hornung A. (2018). Enabling the recycling of high-tech metals -Joined treatment of halogenated plastics with metal containing fractions. 17th International Electronics Recycling Congress - IERC 2018. January 18th, 2018, Salzburg.

ICL Industrial products (2012). Fire protection for automotive and transportation. 6 p. http://icl-ip.com/wp-content/uploads/2012/10/ FR-Transportation-2012.pdf ; http://icl-ip.com/segment_category/ automotive/ . Consulted Jan 2018.

Institute for Environmental Studies (IVM) and University of Amsterdam (IVAM) (2016). POP-BDE waste streams in the Netherlands: analysis and inventory. Report R13-16

Japanese Ministry of the Environment (MOE) (2011). Survey to identify the characteristics of automotive shredder residue (summary)

Jinhui, L., Yuan, C., Wenjing, X., 2017. Polybrominated diphenyl ethers in articles: a review of its applications and legislation. Environ. Sci. Pollut. Res. 24, 4312-4321. https://doi.org/10.1007/s11356-0154515-6

Kajiwara, N., Takigami, H., 2013. Emission behavior of hexabromocyclododecanes and polybrominated diphenyl ethers from flame-retardant-treated textiles. Environ. Sci. Process. Impacts 15, 19571963. https://doi.org/10.1039/c3em00359k

Leslie H A, Leonard P E G, Brandsma S H, de Boer J, Jonkers N. (2016). Propelling plastics into the circular economy - weeding out the toxics ?rst. Environment International 94 (2016) 230-234.

Morf, L.S., Tremp, J., Gloor, R., Huber, Y., Stengele, M., Zennegg, M., 2005. Brominated flame retardants in waste electrical and electronic equipment: Substance flows in a recycling plant. Environ. Sci. Technol. 39, 8691-8699. https://doi.org/10.1021/es051170k

Morin N.A.O, Andersson P L, Hale S E, Arp H P. (2017). The presence and partitioning behavior of flame retardants in waste, leachate, and air particles from Norwegian waste-handling facilities. $J$ of Environmental Sciences, 62 (2017), 115-132.

Niinipuu M. (2013). A comparative evaluation of brominated compounds in end-of-life vehicles. Polybrominated diphenyl ethers and polybrominated dibenzo-pdioxins and dibenzofurans in car seats. Master's thesis at the Department of Chemistry, Umeå University, Sweden

Norwegian Climate and Pollution Agency (2012). Assessment of the need for new requirements for the environmentally sound treatment of end-of-life vehicles. March 2012. Mepex, Frode Syversen. $74 \mathrm{p}$.

Norwegian Climate and Pollution Agency, Mepex, 2012. Assessment of the need for new requirements for the environmentally sound treatment of end-of-life vehicles.

Norwegian Environment Agency (2015). Literature Study - DecaBDE in waste streams. Final Report. Reference number: 2015/10094. 11 December 2015. BiPRO GmbH, Alexander Potrykus. 160 p. (Meta reference presenting results of 17 citations other than the ones cited in this reference list, with less abundant data, and source not fully defined).

Norwegian Environment Agency (2016). Consultancy service on collecting, summarising and analysing information on c-decaBDE in waste - Analysis of the information received by the Basel Convention related to c-decaBDE as called for in decision BC-12/3. Reference number: 2016/4072. Final Report. BIPRO. Potrykus A. 25 p.

Norwegian Environment Agency (2017). Consultancy service on updating the Basel Convention Technical Guidelines to include information on decaBDE. Case number: 2017/5815. Supplementary Information on Destruction Technologies. Alexander Potrykus, BiPRO $\mathrm{GmbH}$. 30th November 2017. $19 \mathrm{p}$.

Petreas M., Oros D. (2009). Polybrominated diphenyl ethers in California wastestreams. Chemosphere, 74

PlasticsEurope 2018. Plastics - the Facts 2018 - An analysis of European plastics production, demand and waste data. $60 \mathrm{p}$. https:// issuu.com/plasticseuropeebook/docs/plastics_the_facts_2018afweb

Puype F, Samsonek J, Knoop J, Egelkraut-Holthus M, Ortlieb M. (2015). Evidence of waste electrical and electronic equipment (WEEE) relevant substances in polymeric food-contact articles sold on the European market. Food Addit. Contam. Part A 32, 410-426.
Rani, M., W. J. Shim, et al. (2014). "Hexabromocyclododecane in polystyrene-based consumer products: An evidence of unregulated use." Chemosphere 110: 111-119.

Risk and Policy Analysis (consulting company) (Georgalas B, Sanchez A, Zarogiannis P) (2014). European Chemical Agency 2014. Support to an annex XV dossier on bis-(pentabromophenyl) ether (decaBDE). J832/ECHA DecaBDE Final report

Sindiku, O., Babayemi, J.O., Tysklind, M., Osibanjo, O., Weber, R., Watson, A., Schlummer, M., Lundstedt, S., 2015. Polybrominated dibenzo-p-dioxins and dibenzofurans (PBDD/Fs) in e-waste plastic in Nigeria. Environ. Sci. Pollut. Res. 22, 14515-14529. https://doi. org/10.1007/s11356-015-5260-6

Sinkkonen S., Paasivirta J., Lahtiperä M., Vattulainen A. (2004). Screening of halogenated aromatic compounds in some raw material lots for an aluminum recycling plant. Environment International, 30

SMMT - Society of Motor Manufacturers and Traders (2016). Analysis of Automotive Shredder Residue from the Composition, Recycling and Recovery Trial for End of Life Vehicles in the United Kingdom. Arrichiello J and Davison P. Mayer Environmental. April 2016. 14 p.

Stubbings, W.A., Harrad, S., 2014. Extent and mechanisms of brominated flame retardant emissions from waste soft furnishings and fabrics: A critical review. Environ. Int. 71, 164-175. https://doi. org/10.1016/j.envint.2014.06.007

Swerea IVF (2018). Strååt M, Nilsson C. Decabromodiphenyl ether and other flame retardants in plastic waste destined for recycling. Project Report $5170721 \mathrm{M}-973 \mid 2018$. Contract number: 16128142. 2018.02.23. 29 p.

Swiss Agency for the Environment, Forests and Landscape (2003). Selected polybrominated flame retardants PBDEs and TBBPA, Berne.

Taurino, R., Pozzi, P., Zanasi, T., 2010. Facile characterization of polymer fractions from waste electrical and electronic equipment (WEEE) for mechanical recycling. Waste Manag. 30, 2601-2607. https://doi.org/10.1016/j.wasman.2010.07.014

Turner, A., Filella, M., 2017a. Field-portable-XRF reveals the ubiquity of antimony in plastic consumer products. Sci. Total Environ. 584585, 982-989. https://doi.org/10.1016/j.scitotenv.2017.01.149

Turner, A., Filella, M., 2017b. Bromine in plastic consumer products Evidence for the widespread recycling of electronic waste. Sci. Total Environ. 601-602, 374-379. https://doi.org/10.1016/j.scitotenv.2017.05.173

UNEP (2017a). United Nations Environmental Programme and Stockholm Convention. 2017. UNEP/POPS/COP.8/32. Stockholm Convention on Persistent Organic Pollutants. Conference of the Parties to the Stockholm Convention on Persistent Organic Pollutants. Eighth meeting. Geneva, 24 April-5 May 2017. Report of the Conference of the Parties to the Stockholm Convention on Persistent Organic Pollutants on the work of its eighth meeting. SC-8/10: Listing of decabromodiphenyl ether (commercial mixture, c-decaBDE). P 64/114. 13 July 2017. http://chm.pops.int/TheConvention/ConferenceoftheParties/Meetings/COP8/tabid/5309/Default.aspx

UNEP 2017b. Proposal to list perfluorohexane sulfonic acid (CAS No: 355-46-4, PFHxS), its salts and PFHxS-related compounds in Annexes $A, B$ and/or $C$ to the Stockholm Convention on Persistent Organic Pollutants. UNEP/POPS/POPRC.13/4*. Stockholm Convention on Persistent Organic Pollutants. 5 June 2017

Vojta S, Betanova J, Melymuk L, Komprdova K, Kohoutek J, Kukucka P, Klanova J (2017). Screening for halogenated flame retardants in European consumer products, building materials and wastes. Chemosphere 168: 457-466

Wäger P, Schluep M, Müller E, Gloor R. (2012). RoHS regulated Substances in Mixed Plastics from Waste Electrical and Electronic Equipment. Environ. Sci. Technol. 2012, 46, 628?635.

Wäger P, Schluep M, Müller E. (2010). RoHS Substances in Mixed Plastics from Waste Electrical and Electronic Equipment. Final Report, September 17, 2010. Empa - Swiss Federal Laboratories for Materials Science and Technology (EMPA). $113 \mathrm{p}$

WRc (consulting company) (2012). Peacock J., Turrell J., Lewin K. Glennie E. 2012. Analysis of Poly-Brominated Biphenyl Ethers (PBDEs) in Selected UK Waste Streams: PBDEs in waste electrical and electronic equipment (WEEE) and end of life vehicles (ELV). Fina report for Defra, Report No.: UC8720.05

WRc (consulting company) Addendum (2012). Peacock J., Turrell J. Lewin K., Glennie E. 2012. Analysis of Poly-Brominated Diphenyl Ethers (PBDEs) in UK Waste Streams: PBDEs in end of life vehicles (ELV) - Addendum to WRc Report UC8720.04 (January 2012). 
TABLE S1: Concentrations of some brominated flame retardants in car parts, end-of-life vehicles, automotive shredder residue (ASR) and post shredder treatment fractions - unweighted mean concentrations from literature data.

\begin{tabular}{|c|c|c|c|c|c|}
\hline Mean Concentration (mg/kg) & PBDE & of which DecaBDE & HBCCD & TBBPA & All \\
\hline Car (117 data) & 3212 & 5432 & 431 & 27 & 2651 \\
\hline 1990-1994 - Printed circuit board & 77 & 200 & 10 & 26 & 53 \\
\hline 1995-1999 \#1 - Printed circuit board & 4 & 10 & 10 & 20 & 8 \\
\hline 1995-1999 \#2 - Printed circuit board & 10 & 10 & 10 & 87 & 26 \\
\hline 2000-2004 - Printed circuit board & 27 & 50 & 10 & 20 & 22 \\
\hline Airbag & 27 & 50 & 50 & 20 & 30 \\
\hline Car & 128 & 128 & & & 128 \\
\hline Car interior & 8 & 14 & & & 8 \\
\hline Car seat cover & 256 & 256 & & & 256 \\
\hline Car seats & 66 & 66 & & & 66 \\
\hline European ELV parts & 3469 & 5751 & & & 3469 \\
\hline Interior 1 & 5677 & 17000 & 50 & 20 & 3420 \\
\hline Interior material 1 & 9 & & & & 9 \\
\hline Interior material 2 & 137 & & & & 137 \\
\hline Interior Mazda 1998 & 52 & 52 & & & 52 \\
\hline Interior Pontiac 1997 & 18 & 18 & & & 18 \\
\hline Luggage compartment & 27 & 50 & 50 & 20 & 30 \\
\hline Printed circuit boards sample 1 & 2 & & & & 2 \\
\hline Printed circuit boards sample 3 & 2 & & & & 2 \\
\hline Printed circuit boards sample 4 & 2 & & & & 2 \\
\hline PUF from old car seats & 1 & 1 & & & 1 \\
\hline PUF from old car seats, high contamination & 900 & & & & 900 \\
\hline PUF from old car seats, low contamination & 1 & & & & 1 \\
\hline PUF from US car seats & 24 & 9 & & & 24 \\
\hline PUF Pontiac 1997 & 8676 & 522 & & & 8676 \\
\hline PUR foam for automotive applications & 40000 & & & & 40000 \\
\hline Radiator, outer & 27 & 50 & 50 & 20 & 30 \\
\hline Rail vehicles & 85000 & 85000 & & & 85000 \\
\hline Seat cover & 9020 & 27000 & 50 & 20 & 5426 \\
\hline Seat cover material & 51 & & & & 51 \\
\hline Seat cover Mazda 1998 & 22700 & 22700 & & & 22700 \\
\hline Seat cover Pontiac 1997 & 8625 & 22500 & & & 8625 \\
\hline Soundproofing 1 & 27 & 50 & 4400 & 20 & 900 \\
\hline Soundproofing 2 & 2343 & 7000 & 50 & 20 & 1420 \\
\hline US/Asian ELV plastic parts & 21 & 37 & & & 21 \\
\hline ELV (46 data) & 925 & 3253 & 337 & & 797 \\
\hline ELV foams & 111 & 33 & 1 & & 74 \\
\hline ELV upholstery & 4053 & 8101 & 842 & & 2983 \\
\hline Hyundai - foam & 0 & 0 & 0 & & 0 \\
\hline Škoda - foam & 0 & 0 & 0 & & 0 \\
\hline ASR (51 data) & 179 & 386 & & & 179 \\
\hline ASR & 254 & 429 & & & 254 \\
\hline Autoshredder Waste & 44 & 44 & & & 44 \\
\hline Input Car shredder residue & 6 & 17 & & & 6 \\
\hline
\end{tabular}




\begin{tabular}{|c|c|c|c|c|c|}
\hline Light ASR (foam and textile) & 21 & & & & 21 \\
\hline Mixed light plastic & 3 & & & & 3 \\
\hline Mixed SR & 255 & 413 & & & 255 \\
\hline PST (33 data) (ELV and WEEE) & 44 & 101 & & & 44 \\
\hline $1,1<$ density $<1,3$ & 364 & 810 & & & 364 \\
\hline $1,1<\mathrm{d}<1,3$ (black hard) & 1 & 2 & & & 1 \\
\hline $1,1<\mathrm{d}<1,3$ (black soft) & 2 & 6 & & & 2 \\
\hline $1,1<\mathrm{d}<1,3$ (coloured) & 0 & 1 & & & 0 \\
\hline $1,1<\mathrm{d}<1,3$ (white/grey) & 5 & 3 & & & 5 \\
\hline $\mathrm{d}<1,1$ (hard plastic) & 0 & 0 & & & 0 \\
\hline density $(0-1)$ & 10 & 27 & & & 10 \\
\hline density $<1,1$ & 2 & 6 & & & 2 \\
\hline Fiber fraction (foam) & 43 & 113 & & & 43 \\
\hline Input for PST & 10 & 29 & & & 10 \\
\hline Total (247 data) & 1623 & 3102 & 386 & 27 & 1447 \\
\hline
\end{tabular}

TABLE S2: Concentrations of some brominated flame retardants in plastics of construction - Unweighted average concentrations from bibliographic data.

\begin{tabular}{|c|c|c|c|c|c|c|c|}
\hline Mean concentration (mg/kg) & PBDE & $\begin{array}{l}\text { of which } \\
\text { DecaBDE }\end{array}$ & HBCDD & TBBPA & $\begin{array}{c}\text { Mean PBDE } \\
\text { HBCDD } \\
\text { TBBPA }\end{array}$ & $\mathbf{n}$ & Interpretation \\
\hline epoxy adhesive & 300000 & 300000 & & & 300000 & 1 & $\begin{array}{l}\text { with PBDE - } \\
\text { decaBDE }\end{array}$ \\
\hline electrical insulation & 200000 & 200000 & & & 200000 & 2 & \\
\hline polyurethane foam (PUR) & 130000 & & & & 130000 & 4 & \\
\hline construction 2 & 4799 & & & & 4799 & 1 & \\
\hline moisture-resistant membrane / film & 1000 & 1000 & & & 1000 & 1 & \\
\hline pipe insulation & 63 & 626 & 0 & & 57 & 11 & \\
\hline recycled plastics & 2 & 18 & 1 & & 2 & 11 & \\
\hline phenolic foam insulation & 0 & 4 & 0 & & 0 & 11 & \\
\hline foam insulation & 0 & 1 & 0 & & 0 & 33 & \\
\hline blue sealing foam & 0 & 0 & 5400 & & 491 & 11 & with HBCDD \\
\hline expanded polystyrene (EPS) & 0 & 0 & 1995 & 0 & 816 & 22 & \\
\hline pale mounting foam & 0 & 0 & 832 & & 76 & 11 & \\
\hline air conditioning - aluminum foil & 1 & 6 & 545 & & 50 & 11 & \\
\hline polystyrene & 0 & 0 & 469 & & 43 & 11 & \\
\hline polystyrene construction & 0 & 0 & 469 & & 43 & 11 & \\
\hline air conditioning - inner sheet & 0 & 0 & 412 & & 37 & 11 & \\
\hline fiber network & 0 & 0 & 250 & & 23 & 11 & \\
\hline polystyrene board & 0 & 0 & 127 & & 12 & 11 & \\
\hline extruded polystyrene (XPS) & 0 & 0 & 28 & 0 & 10 & 14 & \\
\hline air conditioning - cellophane sheet & 0 & 0 & 16 & & 1 & 11 & \\
\hline drywall & 0 & 0 & 9 & & 1 & 11 & \\
\hline HARDSIL NT insulation & 0 & 0 & 8 & & 1 & 11 & \\
\hline air conditioning - fiberglass foam & 0 & 0 & 8 & & 1 & 11 & \\
\hline yellow mounting foam & 0 & 0 & 3 & & 0 & 11 & \\
\hline green mounting foam & 0 & 0 & 2 & & 0 & 11 & \\
\hline polyacrylate material & 0 & 0 & 1 & & 0 & 11 & \\
\hline laminate plastic flooring & 0 & 0 & 1 & & 0 & 11 & \\
\hline window corner cap & 0 & 0 & 0 & & 0 & 11 & without BFR \\
\hline
\end{tabular}




\begin{tabular}{|c|c|c|c|c|c|c|}
\hline heat exchanger & 0 & 0 & 0 & & 0 & 11 \\
\hline insulation board & 0 & 0 & 0 & & 0 & 11 \\
\hline unknown (construction site) & & & 0 & & 0 & 1 \\
\hline insulation aluminum foil & 0 & 0 & 0 & & 0 & 11 \\
\hline paper insulation & 0 & 0 & 0 & & 0 & 11 \\
\hline exterior paint & 0 & 0 & 0 & & 0 & 11 \\
\hline wood fiber insulation & 0 & 0 & 0 & & 0 & 33 \\
\hline rubber & 0 & 0 & 0 & & 0 & 11 \\
\hline plaster & 0 & 0 & 0 & & 0 & 11 \\
\hline asphalt insulation & 0 & 0 & 0 & & 0 & 11 \\
\hline formica & 0 & 0 & 0 & & 0 & 11 \\
\hline oriented strand board (OSB) & 0 & 0 & 0 & & 0 & 55 \\
\hline construction 1 & 0 & & & & 0 & 1 \\
\hline chipboard & 0 & 0 & 0 & & 0 & 55 \\
\hline green sealing foam & 0 & 0 & 0 & & 0 & 11 \\
\hline water resistant paint & 0 & 0 & 0 & & 0 & 11 \\
\hline window finishing tip & 0 & 0 & 0 & & 0 & 22 \\
\hline cotton insulation & 0 & 0 & 0 & & 0 & 11 \\
\hline mastic & 0 & 0 & 0 & & 0 & 22 \\
\hline $\begin{array}{l}\text { paper insulation of recycled bever- } \\
\text { age cartons }\end{array}$ & 0 & 0 & 0 & & 0 & 11 \\
\hline decorative polystyrene & 0 & 0 & 0 & & 0 & 11 \\
\hline insulation hemp rope & 0 & 0 & 0 & & 0 & 11 \\
\hline Drain pipe & 0 & 0 & 0 & & 0 & 11 \\
\hline foam & 0 & 0 & 0 & & 0 & 11 \\
\hline plank of wood & 0 & 0 & 0 & & 0 & 22 \\
\hline brown chipboard & 0 & 0 & 0 & & 0 & 11 \\
\hline elastic linoleum & 0 & 0 & 0 & & 0 & 22 \\
\hline linoleum & 0 & 0 & 0 & & 0 & 22 \\
\hline blown cellulose insulation & 0 & 0 & 0 & & 0 & 11 \\
\hline plaster with fire retardant foam & 0 & 0 & 0 & & 0 & 11 \\
\hline blow insulation made of paper & 0 & 0 & 0 & & 0 & 11 \\
\hline building polystyrene panel & 0 & 0 & 0 & & 0 & 11 \\
\hline drinking water pipe & 0 & 0 & 0 & & 0 & 11 \\
\hline Total & 1713 & 8662 & 317 & 0 & 1555 & 806 \\
\hline
\end{tabular}

TABLE S3: Concentrations of some brominated flame retardants in textile plastics - Unweighted average concentrations from literature.

\begin{tabular}{|c|c|c|c|c|c|c|c|}
\hline Mean concentration $(\mathrm{mg} / \mathrm{kg})$ & PBDE & $\begin{array}{l}\text { of which } \\
\text { DecaBDE }\end{array}$ & HBCDD & TBBPA & $\begin{array}{l}\text { Mean PBDE } \\
\text { HBCDD } \\
\text { TBBPA }\end{array}$ & n & Interpretation \\
\hline $\begin{array}{l}\text { commercial decaBDE treated poly- } \\
\text { ester upholstery fabrics used in the } \\
\text { manufacture of curtains }\end{array}$ & 120000 & 120000 & & & 120000 & 2 & $\begin{array}{l}\text { with PBDE - } \\
\text { DecaBDE }\end{array}$ \\
\hline PUR foam for upholstered furniture & 41040 & & & & 41040 & 11 & \\
\hline various textiles & 39850 & 39850 & & & 39850 & 11 & \\
\hline adhesive layer of reflective tapes & 30000 & 30000 & & & 30000 & 11 & \\
\hline polyester & 28131 & 120000 & 3 & & 25318 & 11 & \\
\hline PUR foam for mattresses & 25000 & & & & 25000 & 2 & \\
\hline textile 2 & 20003 & & & & 20003 & 12 & \\
\hline textile 1 & 11843 & & & & 11843 & 11 & \\
\hline foam padding & 7023 & 7023 & & & 7023 & 2 & \\
\hline
\end{tabular}




\begin{tabular}{|c|c|c|c|c|c|c|}
\hline window blinds & 4799 & 4799 & & 4799 & 11 & \\
\hline several carpets & 907 & 1810 & 7 & 607 & 44 & \\
\hline several mattresses & 115 & 230 & 3 & 78 & 12 & \\
\hline carpet & 85 & 85 & & 85 & 12 & \\
\hline velvet $(70-80 \mathrm{~g} / \mathrm{m} 2)$ & 27 & 27 & & 27 & 22 & \\
\hline flat woven $(30-80 \mathrm{~g} / \mathrm{m} 2)$ & 21 & 21 & & 21 & 22 & \\
\hline cotton $(30-40 \mathrm{~g} / \mathrm{m} 2)$ & 13 & 13 & & 13 & 11 & \\
\hline tents & 2 & 2 & & 2 & 12 & \\
\hline insulation / carpet & 1 & 2 & & 1 & 11 & \\
\hline polyester & 1 & 5 & 42500 & 4251 & 46 & $\begin{array}{l}\text { with HBCDD } \\
\text { and with or } \\
\text { without PBDE } \\
\text { - decaBDE }\end{array}$ \\
\hline furnishing & 9999 & 19953 & 15050 & 11683 & 1 & \\
\hline curtain & 0 & 0 & 8333 & 1087 & 2 & \\
\hline furniture foam filling & 1060 & 2119 & 2275 & 1465 & 12 & \\
\hline curtains & 7 & 14 & 15 & 10 & 4 & \\
\hline Persian rug & 0 & 0 & 1 & 0 & 11 & \\
\hline treated textile & 0 & & & 0 & 11 & Sans RFB \\
\hline Red carpet & 0 & 0 & 0 & 0 & 10 & \\
\hline gray carpet & 0 & 0 & 0 & 0 & 20 & \\
\hline blanket & 0 & 0 & 0 & 0 & 2 & \\
\hline green carpet & 0 & 0 & 0 & 0 & 5 & \\
\hline tablecloth & 0 & 0 & 0 & 0 & 11 & \\
\hline foam & 0 & 0 & 0 & 0 & 22 & \\
\hline textile material & 0 & 0 & 0 & 0 & 1 & \\
\hline blue carpet & 0 & 0 & 0 & 0 & 11 & \\
\hline brown carpet & 0 & 0 & 0 & 0 & 1 & \\
\hline coconut fiber & 0 & 0 & 0 & 0 & 1 & \\
\hline textile cover & 0 & 0 & 0 & 0 & 11 & \\
\hline stuffing material & 0 & 0 & 0 & 0 & 44 & \\
\hline pillow & 0 & 0 & 0 & 0 & 1 & \\
\hline plush & 0 & 0 & 0 & 0 & 1 & \\
\hline insulation of the textile bottle & 0 & 0 & 0 & 0 & 33 & \\
\hline wardrobe & 0 & 0 & 0 & 0 & 2 & \\
\hline bed-cover & 0 & 0 & 0 & 0 & 2 & \\
\hline textile & 0 & 0 & 0 & 0 & 1 & \\
\hline Total & 2080 & 6511 & 3465 & 2244 & 496 & \\
\hline
\end{tabular}

